Ks. Marcin WYSOCKI

(Lublin, KUL)

\title{
MODEL DOSKONAŁEGO CHRZEŚCIJANINA W PISMACH ŚW. CYPRIANA Z KARTAGINY
}

W życie ucznia Chrystusa wpisane są chrześcijańska doskonałość i sam proces doskonalenia. Chrześcijanie powołani są do pełni życia chrześcijańskiego i do doskonałości w miłości, czyli są zobowiązani do osiągnięcia świętości i doskonałości własnego stanu. Orędzie Jezusa Chrystusa do ludzi, wzywające do nawrócenia, zawiera wyraźne wezwanie skierowane do uczniów Mistrza z Nazaretu: „Bądźcie więc wy doskonali, jak doskonały jest Ojciec wasz niebieski" (Mt 5, 48). Apostołowie, a po nich szereg pokoleń głosicieli Dobrej Nowiny, nawiązując do tych słów Chrystusa, przedstawiali wiernym obraz doskonałego ucznia Jezusa Chrystusa. Obraz ten, choć niezmienny w swych pryncypiach, opierających się na Dekalogu i Ewangeliach, a z nich w sposób szczególny na Ośmiu Błogosławieństwach, modyfikowany był jednak w zależności od Sitz im Leben poszczególnych grup wierzących. Jednym z duszpasterzy, którzy przedstawiali i wzywali do podjęcia chrześcijańskiej doskonałości, był biskup Kartaginy, św. Cyprian. Jego nastawienie duszpasterskie oraz wyjątkowe okoliczności, w których przyszło mu działać, w sposób szczególny zachęcają do podjęcia badań nad modelem doskonałego chrześcijanina w jego dziełach.

1. Św. biskup Cyprian z Kartaginy i jego czasy. O życiu biskupa Cypriana wiemy stosunkowo niewiele. Przyjmuje się, że urodził się pomiędzy rokiem 200 a 210. Pewne jest, że pochodził z pogańskiej i zamożnej rodziny. Gruntownie wykształcony został szybko znakomitym i sławnym nauczycielem retoryki. Będąc już wziętym retorem i adwokatem kartagińskim w roku 246 ,,pod wpływem kapłana Cecyliusza, którego też przybrał imię, przyjął wiarę katolicką, a cały swój majątek rozdał ubogim". Wkrótce potem został kapłanem, a na przełomie 248 i 249 roku, po śmierci biskupa Kartaginy Donata, zajął jego miejsce wbrew opozycji grupy kapłanów z Nowatem na czele. Przez kolejne prawie 10 lat zarządzał Kościołem kartagińskim zmagając się ze schizmą Nowacjana, problemem upadłych i chrztu heretyków oraz angażując się w działalność charytatywną po

${ }^{1}$ Hieronymus, De viris illustribus 67, PL 23, 677: ,[...] exinde suadente presbytero Caecilio, a quo et cognomentum sortitus est, Christianus factus, omnem substantiam suam pauperibus erogavit”, tłum. W. Szołdrski, PSP 6, 89. 
wybuchu zarazy, która nawiedziła Kartaginę w 252 roku. Został ścięty mieczem w czasie prześladowań za cesarza Waleriana 14 września 258 roku$^{2}$. Ten ostatni akord życia św. Cypriana znamionuje jednocześnie lata jego pontyfikatu, w czasie którego oprócz trudności wewnętrznych Kościoła, musiał stawiać czoła również prześladowaniom, które w owym czasie wybuchły ze szczególną siłą, choć i wcześniejsze lata, pomimo braku historycznie pewnych faktów, nie należały do spokojnych dla chrześcijan ${ }^{3}$. Blisko 70 lat przed prześladowaniami Decjusza żaden chrześcijanin nie mógł czuć się pewnie. Prześladowania i męczeńska śmierć, czas apokalipsy, groziły wyznawcom Jezusa Chrystusa nieustannie i nie pozostawały bez wpływy na poglądy teologiczne chrześcijan.

W okresie pontyfikatu Cypriana znane są dwie fale prześladowań. Pierwsze miały miejsce w roku 249 za cesarza Decjusza, który jako pierwszy w sposób zorganizowany i na szeroką skalę rozpoczął ogólnoimperialne akty prześladowcze. Przyczyny ich rozpoczęcia nie są znane i są przedmiotem licznych badań i teorii ${ }^{4}$. Podobnie jak w przypadku wcześniejszych wydarzeń nie znamy brzmienia edyktów, które otwierały drogę do prześladowania. Były to jednak pierwsze wystąpienia władzy przeciwko Kościołowi udokumentowane w sposób dość wystarczający, szczególnie jeśli chodzi o terytorium Afryki prokonsularnej, gdzie mamy zachowane pierwszorzędne świadectwo w postaci pism św. Cypriana, biskupa Kartaginy ${ }^{5}$.

Prawdopodobnie prześladowania Decjusza miały dwie fazy ${ }^{6}$. Pierwsza rozpoczęła się wkrótce po przybyciu cesarza do Rzymu w końcu 249 roku i stanowiła swego rodzaju kontynuację wystąpienia Maksymianusa ${ }^{7}$. W jej wyniku aresztowano przede wszystkim głowy lokalnych Kościołów w Rzymie, Antiochii i w Jerozolimie ${ }^{8}$. W Kartaginie i Aleksandrii biskupi Cyprian i Dionizjusz opuścili miasta, chroniąc się przed prześladowaniami ${ }^{9}$. Druga

${ }^{2}$ Por. Cyprian, SWP 105-109; V. Saxer, Cipriano di Cartagine, DPAC I 678-683; A. Hoffmann, Cipriano, w: Dizionario di letteratura cristiana antica, ed. S. Döpp - W. Geerlings, Città del Vaticano 2006, 183-189; E.W. Benson, Cyprian. His life, his times, his work, New York 1897, J.P. Burns, Cyprian the Bishop, London 2002.

${ }^{3}$ Por. Tertullianus, Ad Scapulam III 5; Cyprianus, Epistula 39, 2-3; Eusebius, HE VI 28, 41; Herodianus, Ab excessu divi Marci historia VII 1, 2-4, 8. 7; Scriptores Historiae Augustae: Maximinus 9, 7-8; zob. też T.D. Barnes, Tertullian: a historical and literary study, Oxford 2005, 158, W.H.C. Frend, Martyrdom and persecution in the Early Church. A study of a conflict from the Maccabees to Donatus, New York 1967, 285-292.

${ }^{4}$ Por. G.T. Oborn, Why did Decius and Valerian proscribe Christianity, ChH 2 (1933) 67-77; W. Clarke, Some observations on the persecution of Decius, „Antichton” 3 (1969) 63-76; J.B. Rives, The Decree of Decius and the religion of Empire, JRS 89 (1999) 135-154.

${ }^{5}$ Por. C. Saumage, La persécution de Dèce en Afrique d'après la correspondance de S. Cyprien, „Byzantion” 32 (1962) 1-29.

${ }^{6}$ Por. Frend, Martyrdom, s. 301.

${ }^{7}$ Por. Epistula 37, 2, CCL 3B, 178-180.

${ }^{8}$ Por. Eusebius, HE VI 39.

${ }^{9}$ Por. tamże VI 40. 
faza rozpoczęła się z chwilą, gdy wobec napotkanego oporu, Decjusz wydał, prawdopodobnie w lutym 250 r., powszechny nakaz składania ofiar, który był wprowadzany w kolejnych prowincjach wiosną i latem tego roku. Wydaje się, iż w Kartaginie okres składania ofiar został ograniczony do bardzo krótkiego czasu $^{10}$. Odzew na cesarski edykt był zaś dość znaczny, skoro wkrótce po jego wydaniu Cyprian zachęcał:

„Módlmy się wzdychając i płacząc tak, jak powinni się modlić ci, którzy żyją wśród poległych; wśród resztek przerażonych, wśród licznej gromady obojętnych i małej liczby tych, którzy się trzymają"11.

W napisanym zaś w roku 251 traktacie De lapsis wspominał:

„Na pierwsze zaraz słowa grożącego nieprzyjaciela bardzo wielka liczba braci wiarę swoją zdradziła; obaleni zostali nie atakiem prześladowania, lecz własnym dobrowolnym upadkiem"12.

Ci, którzy uporczywie odmawiali żądaniom wyznaczonych urzędników, byli więzieni i stawiani przed trybunały. Niektórzy z nich byli zwalniani, a inni wysyłani na zesłanie ${ }^{13}$. W kwietniu $250 \mathrm{r}$. władze wprowadziły do przesłuchań tortury oraz inne środki w postaci pozbawiania wody, żywności, powietrza czy światła, aby zmusić chrześcijan do złożenia ofiar ${ }^{14}$. Wśród ofiar tego surowego prześladowania byli w Kartaginie, jak pisał św. Cyprian:

„Bassus w kamieniołomach, Mappalik na torturach, Fortunion w więzieniu, Paweł w śledztwie, Fortunata, Wiktoryn, Wiktor, Herreniusz, Kredula, Hereda, Donat, Firmus, Wenustus, Fruktus, Iulia, Marcjalis i Ariston, ci z woli Boga zginęli w więzieniu z powodu głodu"15,

ale także wspominani w dniu 10 kwietnia: Terencjusz, Afrykanus, Maksymiusz, Pompeus, Zenon, Aleksander i Teodor ${ }^{16}$, którzy zostali ukarani przez ówczesne-

${ }^{10}$ Por. Frend, Martyrdom, s. 302.

${ }^{11}$ Epistula 11, 8, CCL 3B, 65-66: „Nos [...] deprecemur, cum gemitu pariter et fletu deprecantes, sicut deprecari oportet eos qui sint positi inter plangentium ruinas et timentium reliquias, inter numerosam languentium stragem et exiguam stantium paucitatem", tłum. W. Szołdrski, PSP 1, 55.

${ }^{12}$ De lapsis 7, CCL 3, 224: „Ad prima statim verba minantis inimici maximus fratrum numerus fidem suam prodidit, nec prostratus est persecutionis impetu, sed voluntario lapsu se ipse prostravit", tłum. J. Czuj, POK 19, 201.

${ }^{13}$ Por. Epistulae 6, 1-2; 12; 14, 2; 19, 2; zob. J.P. Burns, Cyprian the Bishop, London 2002, 1-2.

${ }^{14}$ Por. Epistulae 10, 1-2; 12, 1; 20, 2; 21, 4; 22, 2.

${ }^{15}$ Epistula 22, 2, CCL 3B, 118: „quorum nomina subicio, Bassi in pignerario, Mappalici in quaestione, Fortunionis in carcerem, Paulus a quaestione, Fortunata, Victorinus, Victor, Herennius, Credula, Hereda, Donatus, Firmus, Venustus, Fructus, Iulia, Martialis et Ariston, qui Deo volente in carcerem fame necati sunt".

${ }^{16}$ Por. G.D. Gordini, BS XII 377-378; ASanc Aprilis I (10 IV), 851-853; Passio Terentii, PG 115, 96-106. 
go prokonsula Afryki Fortunatianusa ${ }^{17}$. Ci, którzy złożyli ofiarę, otrzymywali potwierdzenie (libellus), że należycie spełnili swój obowiązek ${ }^{18}$, potwierdzone - w wypadku Kartaginy - przez pięcioosobową komisję ${ }^{19}$. Zaangażowanie Imperium i cesarza Decjusza w wojnę z królem Gotów nieznacznie osłabiło prześladowanie chrześcijan, a śmierć Imperatora w bitwie pod Abrittus w 251 r. ostatecznie je przerwała. Jednak początkowy sukces władz rzymskich został osiągnięty. Jak stwierdził W. Frend: „Kościół w całym Imperium był zdezorganizowany, rozproszony i chwilowo zdyskredytowany. Jego przywódcy, albo upadli, albo uciekli"20. Jednak już wkrótce Kościół podniósł się z ran zadanych przez Decjusza. Wiosną $251 \mathrm{r}$. Cyprian powrócił z miejsca schronienia i przewodniczył obchodom Wielkanocy i wkrótce po niej, na 15 maja 251 oraz 15 marca $252 \mathrm{r}^{21}$ zwołał do Kartaginy synody biskupów, których głównym zagadnieniem była kwestia upadłych (lapsi) podczas prześladowań.

Druga fala prześladowań okresu pontyfikatu biskupa Cypriana miała miejsce, gdy nowy cesarz Wibiusz Trebonian Gallus (251-253) wraz ze swym synem współrządcą Woluzjanem, rozkazał wznowić w 252 r. szykany wobec chrześcijan ${ }^{22}$. Najbardziej ucierpiał wówczas Kościół w Rzymie, o którym św. Cyprian pisał w liście do Lucjana:

„Poznajemy, najdroższy bracie, i przenikamy całą jasnością naszego serca zbawienne i święte zamiary boskiego Majestatu, jakie się okazały w czasie nagłego prześladowania, jakie u was niedawno wybuchło, a które podjęła władza świecka przeciw Kościołowi Chrystusa i przeciw Korneliuszowi, błogosławionemu męczennikowi, i przeciw wam wszystkim"²3.

Papież Korneliusz został skazany na zesłanie do Centumcellae, gdzie zmarł w czerwcu 253 roku. Również Kościół kartagiński doznał licznych cierpień,

${ }^{17}$ Por. A. Degrassi, I fasti consolari dell'impero romano, Roma 1952, 66; G.W. Clarke, Prosopographycal note on the Epistles of Cyprian, II: The Proconsul of Africa in 250, „Latomus” 31 (1972) 1053-1057; T.D. Barnes, An African Governor under Decius, JTS 25 (1974) 110-112. A. Birley (A persecuting praeses of Numidia under Valerian, JTS 42:1991, 598-610) opierając się na Passio Terentii, umieszcza Juliusza Salustiusza Saturninusa Fortunatianusa jako prześladowcę chrześcijan w Numidii za czasów Waleriana.

${ }^{18}$ Por. J.R. Knipfing, The Libelli of the Decian Persecution, HTR 16 (1923) 345-390; A. Di Berardino, Libellus, NDPAC II 2814-2815; S. Longosz, Libellus, EK X 939-943..

${ }^{19}$ Por. Epistula 43, 3.

${ }^{20}$ Frend, Martyrdom, s. 307: „The Church throughout the Empire was disorganized, dispersed and momentarily discredited. Able leaders had lapsed, others had fled".

${ }^{21}$ Por. Cyprianus, Epistulae 55, 56, 57, 59, w: Dokumenty synodów od 50 do 381 roku, red. A. Baron - H. Pietras, ŹMT 37, Kraków 2006, 6-12.

${ }^{22}$ Por. Eusebius, HE VII 1.

${ }^{23}$ Epistula 61, 3, CCL 3C, 382: „Intellegimus, frater carissime, et tota cordis nostri luce perspicimus divinae maiestatis salutaria et sancta consilia, unde illic repentina persecutio nuper exorta sit, unde contra Ecclesiam Christi et episcopum Cornelium beatum martyrem vosque omnes saecularis potestas subito proruperit”, PSP 1, 198. 
skoro Cyprian w liście skierowanym do Korneliusza, usprawiedliwiając swoje postępowanie z wcześniejszego okresu pisał:

„A w tych dniach, gdy list ten pisałem do Ciebie w sprawie edyktu nakazującego, aby lud brał udział w obrzędach ofiarnych, thum w cyrku znowu głośnymi okrzykami domagał się, aby go [Cypriana - M.W.] wydano lwom"24.

Pierwszy edykt, wydany prawdopodobnie w sierpniu $257 \mathrm{r}^{25}$, dotyczył jedynie duchowieństwa i nakazywał złożenie ofiar oraz że ,nigdy już nie będzie wolno ani wam [kapłanom - M.W.], ani nikomu innemu odbywać zebrań, ani wchodzić na tak zwane cmentarze" 26 . To w oparciu o ten edykt odbywało się przesłuchanie św. Cypriana przez konsula Aspazjusza Paternusa (257-258) w dniu 30 sierpnia 257 r., zakończone skazaniem na wygnanie do Kurubis ${ }^{27}$. Podobnie postąpiono $\mathrm{z}$ biskupem Aleksandrii Dionizjuszem i jego towarzyszami ${ }^{28}$. Na tym przykładzie widać, iż edykt łagodnie traktował chrześcijan i nie nakazywał surowych represji, choć w Numidii legat skazał wielu biskupów i kapłanów na roboty w kopalniach ${ }^{29}$. Drugi edykt opublikowany został latem 258 r. i był skierowany do Senatu z instrukcjami dla zarządców prowincji. Był znacznie ostrzejszy niż poprzedni i dotykał nie tylko kleru, ale także świeckich pochodzących z wyższych sfer i zajmujących wysokie stanowiska, i nakazywał:

„Aby biskupi, prezbiterzy i diakoni zostali zaraz straceni, senatorowie zaś i znakomici mężowie i członkowie rzymskiego rycerskiego stanu po utracie godności mają być pozbawieni majątku; gdyby zaś po jego utracie byli dalej chrześcijanami, mają być również ścięci. Znakomite niewiasty po konfiskacie ich majątku mają być zesłane na wygnanie, będący zaś na służbie cesarskiej, którzy czy to przedtem, czy teraz wyznali [Chrystusa], po konfiskacie ich majątku mają być napiętnowani i w więzach zesłani do dóbr cesarskich”30.

${ }^{24}$ Epistula 59, 6, CCL 3C, 347: „[...] his ipsis etiam diebus quibus has ad te litteras feci ob sacrificia quae edicto proposito celebrare populus iubebatur clamore popularium ad leonem denuo postulatus in circo", PSP 1, 161.

${ }^{25}$ Por. Il cristianesimo nelle leggi di Roma imperiale, red. A. Barzanò, Milano 1996, 46; Frend, Martyrdom, s. 317; P. Paschini, La persecuzione di Valeriano, SRom 6 (1958) 130-137; P. Keresztes, Two edicts of the Emperor Valerian, VigCh 29 (1975) 81-95; K.H. Schwarte, Die Christengesetze Valerians, w: Religion und Gesellschaft in der römischen Kaiserzeit, hrsg. W. Eck, Köln 1989, 103-163.

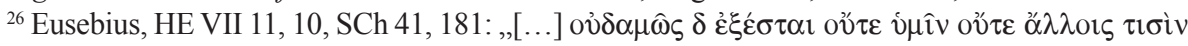

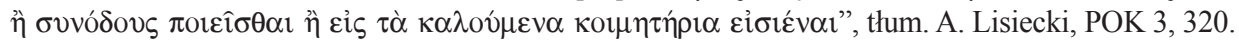

${ }^{27}$ Por. Acta Proconsularia Sancti Cypriani 1-2; zob. W. Wischmeyer, Der Bishof im Prozess. Cyprian als episcopus, patronus, advocatus und Martyr von dem Prokonsul, „Instrumenta Patristica” 19 (1989) 363-371.

${ }^{28}$ Por. Eusebius, HE VII 11, 9-17.

${ }^{29}$ Por. Epistulae 72-80.

${ }^{30}$ Epistula 80, 1, CCL 3C, 626-627: ,[...] ut episcopi et presbyteri et diacones in continenti animadvertantur, senatores vero et egregii viri et equites Romani dignitate amissa etiam bonis spolientur et si ademptis facultatibus christiani esse perseveraverint, capite quoque multentur, matronae ademptis 
Efektem tego edyktu była męczeńska śmierć papieża Sykstusa i czterech diakonów w Rzymie ${ }^{31}$, w Numidii - biskupów Agapiusza i Sekundinusa ${ }^{32}, 300$ męczenników z Massa Candida ${ }^{33}$, biskupa Teogenesa z Hippony ${ }^{34}$, Lucjusza i Montanusa w Kartaginie ${ }^{35}$, a przede wszystkim w dniu 14 września 258 roku, śmierć św. Cypriana, biskupa Kartaginy, za odmowę złożenia ofiary bogom i bycie „biskupem ludzi o świętokradzkiej myśli”36.

Świat z prześladowaniami, zarazą, zgodnie z poglądami Biskupa Kartaginy, nieubłagalnie zatem zmierzał do swego końca. Wierni żyli wśród „wirów świata” (mundi turbines) ${ }^{37}$, w rzeczywistości, w której „było tyle zła i okrucieństwa" (cum tanta in saeculo malitia et sevitia grassetur) ${ }^{38}$ i która jawiła się już jako „ruiny świata” (orbis ruinae) ${ }^{39}$. W tym jednak świecie chrześcijanie mieli do spełnienia szczególne zadanie - mieli być doskonałymi ludźmi, którzy wprowadzą w ów świat choć trochę harmonii, dobra i przygotują go na zbliżający się koniec. Dlatego też potrzebny był wzór doskonałości stosowny do danych czasów. I taki wzór doskonałego chrześcijanina przedstawiał w swoich dziełach św. Cyprian.

2. Doskonałość dla wszystkich. Biskup Cyprian, jako duszpasterz w stołecznej Kartaginie, wielokrotnie ukazywał powszechny wzór doskonałego chrześcijanina, który powinni praktykować wszyscy wierzący. W dziele De oratione Dominica wyraźnie wskazywał, jaka jest wola Boga dotycząca chrześcijańskiej doskonałości:

„Wola zaś Boga jest ta, którą Chrystus czynił i której nauczał. Pokora w obcowaniu, stałość w wierze, skromność w słowach, w czynach sprawiedliwość, w uczynkach miłosierdzie, w obyczajach karność, nieznajomość czynienia krzywdy, a możność znoszenia uczynionej, utrzymywanie z braćmi pokoju, miłowanie Pana z całego serca, ukochanie w nim tego, przez co jest ojcem, a obawa przed tym, przez co jest Bogiem; nie przenosić nic nad Chrystusa, bo i On niczego nad nas nie przenosił, nierozdzielnie trwać w Jego miłości, przy krzyżu Jego odważnie i wiernie stać, gdy o Jego imieniu i godności jest

bonis in exilium relegentur, Caesariani autem quicumque vel prius confessi fuerant vel nunc confessi fuerint confiscentur et vincti in Caesarianas possessiones descripti mittantur”, PSP 1, 306.

${ }^{31}$ Por. tamże.

${ }^{32}$ Por. Passio Mariani et Jacobi 3.

${ }^{33}$ Por. Augustinus, Sermones 306 i 311.

${ }^{34}$ Por. Augustinus, Sermones 273-277.

${ }^{35}$ Por. Passio Sanctorum Montani et Lucii, ed. H. Musurillo: The Acts of the Christian martyrs, Oxford 1972, 214-239.

${ }^{36}$ Acta Proconsularia Sancti Cypriani 3: „Tu papam te sacrilegae mentis hominibus praebuisti”, tamże, s. 172.

${ }^{37}$ Por. De mortalitate 3; De bono patientiae 21; Ad Donatum 14.

${ }^{38}$ Epistula 55, 2, CCL 3B, 257.

${ }^{39}$ Por. De lapsis 26, CCL 3, 235. 
mowa, wykazywać w mowie stałość wyznania, w dyskusji zaufanie, w imię którego się zgromadzamy, w śmierci cierpliwość, za którą koronę otrzymujemy; to znaczy chcieć być współdziedzicami Chrystusa, to znaczy spełniać przykazanie Boga, to znaczy spełniać wolę Ojca"40.

W tym krótkim fragmencie Biskup Kartaginy wymienia praktycznie wszystkie cechy, jakimi winien odznaczać się doskonały chrześcijanin, i które rozwija w innych swych dziełach. Punktem jednak wyjścia dla wszelkich rozważań nad doskonałością chrześcijańską w myśli biskupa Cypriana była zasada jedności w Kościele - zasada miłości i pokoju - która nabierała szczególnego znaczenia w okresie schizm i herezji, o których dowiadujemy się z pism biskupa Kartaginy ${ }^{41}$. Trwanie w Kościele było podstawową cechą doskonałego chrześcijanina według Cypriana i dlatego w jednym ze swoich listów pisał:

„Kimkolwiek i jakimkolwiek jest, na pewno nie jest chrześcijaninem ten, kto nie jest w Kościele Chrystusa. Może się chełpić a swą filozofię i wymowę pysznymi słowy głosić; kto jednak nie trzyma się braterskiej miłości i jedności kościelnej, ten utracił i to, czym był poprzednio"42.

Trwanie w jedności kościelnej związane było zaś z cechą doskonałego chrześcijanina, wielokrotnie podkreślaną przez Cypriana i umieszczoną właściwie na samym początku powyższego fragmentu z De oratione, jaką jest spełnianie przykazań Boga. Przez przykazania biskup Kartaginy rozumie zarówno te dane Mojżeszowi, jak i nakazy, które przekazał swoim uczniom Chrystus oraz przekazuje Kościół. Ich przestrzeganie jest warunkiem sine qua non bycia chrześcijaninem:

„Powinniśmy więc słuchać słów jego, uczyć się, czegokolwiek uczył, i czynić cokolwiek czynił. Zresztą, jak może kto mówić, że wierzy w Chrystusa, jeżeli nie czyni tego, co Chrystus przykazał?"43.

${ }^{40}$ De oratione Dominica 15, CCL 3A, 99: „Voluntas autem Dei est quam Christus et fecit et docuit. Humilitas in conversatione, stabilita in fide, verecundia in verbis, in factis iustitia, in operibus misericordia, in moribus disciplina, iniuriam facere non nosse, et factam posse tolerare, cum fratribus pacem tenere; Deum toto corde diligere, amare in illo quod pater est, timere quod Deus est; Christo nihil omnino praeponere quia nec nobis quicquam ille praeposuit, caritati eius inseparabiliter adhaerere, cruci eius fortiter ac fidenter assistere; quando de eius nomine et honore certamen est, exhibere in sermone constantiam, qua confitemur, in quaestione fiduciam, qua congredimur, in morte patientiam qua coronamur: hoc est cohaeredem Christi velle esse, hoc est praeceptum Dei facere, hoc est voluntatem Patris implere", thum. J. Czuj, POK 19, 235-236.

${ }^{41}$ Por. W. Myszor, Zagadnienie herezji w Listach św. Cypriana, STV 9 (1971) 147-190.

${ }^{42}$ Epistula 55, 24, CCL 3B, 285: „Quisque ille est et qualiscumque est, Christianus non est qui in Christi Ecclesia non est. Iactet se licet et philosophiam vel eloquentiam suam superbis vocibus praedicet, qui nec fraternam caritatem nec ecclesiasticam unitatem tenuit, etiam quod prius fuerat amisit", PSP 1, 156.

${ }^{43}$ De catholicae Ecclesiae unitate 2, CCL 3, 250: „Verbis igitur eius insistere, quaecumque et docuit et fecit discere et facere debemus. Ceterum credere se in Christum quomodo dicit, qui 
Fundamentem wypełniania Bożej woli w życiu chrześcijanina winna być posiadana przez niego karność, która powiązana jest z powinnością i bojaźnią. Cyprian bowiem stwierdza:

„karność, jako stróżka nadziei, podpora wiary, przewodniczka zbawiennej drogi, podnieta i pokarm dobrego umysłu, mistrzyni cnoty, sprawia, że można zawsze trwać w Chrystusie i stale żyć w Bogu, że można dojść do obietnic niebieskich i boskiej nagrody. Zdrową jest rzeczą iść za nią, a zabójczą lekceważyć ją i zaniedbywać" 44 .

Jak można zauważyć, to posłuszeństwo Bożej woli w życiu doskonałych chrześcijan nie ogranicza się do jej znajomości, ale zakłada praktyczne jej wypełnianie w życiu codziennym. Biskup Cyprian wielokrotnie wskazuje na konieczność czynienia tego, co Bóg nakazuje. Przed chrześcijanami kładzie wyraźny nakaz: „Czyń, co jest Chrystusa!”45. W innym miejscu tego samego dzieła, z którego pochodzi to wezwanie doprecyzowuje ten nakaz stwierdzając:

„Jeżeli synami Boga jesteśmy, jeżeli świątyniami jego już być zaczęliśmy, jeżeli po otrzymaniu Ducha Świętego święcie i duchowo żyjemy, jeżeli z ziemi ku niebu oczy podnieśliśmy, jeżeli do rzeczy wyższych i Bożych serce, pełne Boga i Chrystusa skierowaliśmy, nie czynimy nic innego, tylko to, co jest godne Boga i Chrystusa, [...] Którzy zaś w chrzcie według cielesnych grzechów starego człowieka umarli i pogrzebani jesteśmy, którzy w niebieskim odrodzeniu z Chrystusem współzmartwychwstaliśmy, myślmy i czyńmy, co jest Chrystusa [...]"46.

Czynienie tego, co czynił Chrystus jest dla chrześcijan - synów Boga ${ }^{47}$, upodabnianiem się do Niego ${ }^{48}$. Naśladowaniem tego, co czynił Chrystus jako Syn Boży i nasz Brat. I dlatego Cyprian stwierdzał:

non facit quod Christus facere praecepit?", tłum. J. Czuj, POK 19, 172; por. tamże 27; zob. też M. Kosznicki, Kształcenie i wychowanie w literaturze zachodniego chrześcijaństwa od I do IV wie$k u$, Gdańsk 1999, 77-78.

${ }^{44}$ De habitu virginum 1, PL 4, 440-441: „Disciplina custos spei, retinaculum fidei, dux itineris salutaris, fomes ac nutrimentum bonae indolis, magistra virtutis, facit in Christo manere semper ac iugiter Deo vivere et ad promissa caelestia et ad divina praemia pervenire. Hanc et sectari salubre est, et aversari ac negligere lethale", thum. J. Czuj, POK 19, 137; por. tamże 2.

${ }^{45}$ De zelo et livore 10, CCL 3A, 80: ,[...] quae sunt Christi gere”, thum. J. Czuj, POK 19, 375.

${ }^{46}$ Tamże 14, CCL 3A, 82-83: „Si filii Dei sumus, si templa eius esse iam coepimus, si accepto Spiritu Sancto sancte et spiritaliter vivimus, si de terris oculos ad caelum sustulimus, si ad superna et divina plenum Deo et Christo pectus ereximus, non nisi quae sunt Deo et Christo digna faciamus [...]. Qui ergo in baptismo secundum hominis antiqui peccata carnalia et mortui et sepulti sumus, qui regeneratione caelesti Christo consurreximus, quae sunt Christi et cogitemus pariter et geramus", POK 19, 378.

${ }^{47}$ Por. De oratione Dominica 11.

${ }^{48}$ Por. De zelo et livore 14. 
„Jeżeli jesteśmy współdziedzicami Chrystusa, trwajmy w pokoju Chrystusa. Jeżeli jesteśmy dziećmi Boga, winniśmy być miłośnikami pokoju [...]. Synowie Boga powinni być czyniącymi pokój, łagodnego serca, prości w mowie, zgodni w uczuciu, związkami jednomyślności wiernie z sobą złączeni"49.

Pomiędzy chrześcijanami, którzy mają trwać w pokoju i jedności, nie powinno być zatem żadnych kłótni i zazdrości, ponieważ Pan zostawił im pokój, i tylko ten, kto jest zgodny w mowie, kto jest dobry i sprawiedliwy, ten wyznaje Chrystusa i Go naśladuje ${ }^{50}$. Chrześcijaninowi nie wolno zatem nienawidzieć $^{51}$, lecz trzeba zabiegać o miłość i łagodność ${ }^{52}$. Cyprian stwierdzał, że „w domu Boga, w Kościele Chrystusa, mieszkają jednomyślni, przebywają zgodni i szczerzy"53. Praktyczną zaś implikacją tego jest przede wszystkim troska o ubogich i potrzebujących pomocy:

„Przeto w Ewangelii Pan, nauczyciel naszego życia i mistrz zbawienia wiecznego, ożywiając naród wierzących, a zaradzając ożywianym na wieczność, niczego wśród swych boskich przykazań i przepisów niebieskich częściej nie nakazuje i nie poleca, jak byśmy nieustannie troskali się o dawanie jałmużn i zamiast ziemskich posiadłości niebieskie raczej skarby gromadzili [...]. A gdy przy zachowaniu prawa chciał pokazać, na czym polega doskonałość, mówi: «Jeśli chcesz być doskonałym, idź, sprzedaj, co masz, i daj ubogim, a będziesz miał skarb w niebie; a przyjdź, pójdź za mną»" ${ }^{54}$.

Podkreślając wagę jałmużny w życiu chrześcijan wskazuje zarazem Cyprian na to, że dając jałmużnę należy być bezstronnym i sprawiedliwym, aby w ten sposób stawać się naśladowcą Boga Ojca ${ }^{55}$. Świadczenie jałmużny związane jest w myśli Biskupa Kartaginy z wyrzeczeniem się świata. Doskonały chrześcijanin powinien wyrzec się wszystkiego, co łączy go ze światem:

${ }^{49}$ De catholicae Ecclesiae unitate 24, CCL 3, 267: „Si heredes Christi sumus, in Christi pace maneamus; si filii Dei sumus, pacifici esse debemus. [...] Pacificos esse oportet Dei filios, corde mites, sermone simplices, adfectione concordes, fideliter sibi unanimitatis nexibus cohaerentes", POK 19, 192; por. De oratione Dominica 23-24.

${ }^{50}$ Por. Epistula 13, 5.

${ }^{51}$ Por. Ad Demetrianum 25.

${ }^{52}$ Por. De catholicae Ecclesiae unitate 9.

${ }^{53}$ De catholicae Ecclesiae unitate 8, CCL 3, 255: „In domo Dei, in Ecclesia Christi, unianimes habitant, concordes et simplices perseverant", POK 19, 178.

${ }^{54}$ De opere et eleemosynis 7, CCL 3A, 59: „Itaque in evangelio Dominus doctor vitae nostrae et magister salutis aeternae vivificans credentium populum et vivificatis consulens in aeternum inter sua mandata divina et praecepta caelestia nihil crebrius mandat et praecipit quam ut insistamus eleemosynis dandis, nec terrenis possessionibus incubemus, sed caelestes thesauros potius recondamus. [...] Et cum observata lege perfectum et consummatum vellet ostendere. «Si vis, inquit, perfectus esse, vade et vende omnia tua et da egenis, et habebis thesaurum in caelo; et veni, sequere me»", POK 19, 332.

${ }^{55}$ Por. De opere et eleemosynis 25. 
„Przeciwnie natomiast uczy Pan, że doskonałym i całym człowiekiem staje się ten, kto wszystko sprzedawszy i na użytek ubogich rozdzieliwszy, skarb sobie zakłada w niebie. Mówi, iż ten może iść za nim i naśladować chwałę męki Pańskiej, kto gotów i podkasany, żadnymi węzłami majętności nie jest skrępowany, lecz swobodny i wolny, idzie sam także za mieniem, do Boga przedtem wysłanym" 56 .

Doskonałego chrześcijanina nie mogą zatem powstrzymywać więzy majątkowe $^{57}$, ani też sprawy życia światowego ${ }^{58}$, lecz powinien on dążyć za rzeczami wiecznymi i boskimi i wszystko czynić według woli Bożej i naśladować w tym wyrzeczeniu Chrystusa ${ }^{59}$.

Doskonały chrześcijanin powinien w tym wszystkim, według św. Cypriana, kierować się cierpliwością - „cnota ta bowiem jest nam wspólna z Bogiem”60, powinien kroczyć drogą prawa i sprawiedliwości ${ }^{61}$, „,bardziej musi walczyć z diabłem"62, a przy tym, gdy Pan:

„,każe nam być prostymi w niewinności, a jednak w prostocie roztropnymi, cóż innego [...], wypada mam czynić, jak nie mieć się na baczności i troskliwie czuwać, by zarówno rozumieć zasadzki chytrego wroga i strzec się ich"63.

Co zaś nie powinno budzić zdziwienia, według Cypriana, najdoskonalszym sposobem czuwania i walki z diabłem jest modlitwa, którą winien pielęgnować każdy chrześcijanin:

„Dla chrześcijan nie ma godziny, w której by często i zawsze nie należało czcić Boga, byśmy, którzy jesteśmy w Chrystusie, to jest, w prawdziwym słońcu i dniu, przez cały dzień trwali na modlitwie; a kiedy według praw świata na zmianę, noc przychodzi, ciemności nocne modlącym się żadnej szkody czynić nie mogą, ponieważ dla synów światłości dzień jest i w nocy"64.

${ }^{56}$ De oratione Dominica 20, CCL 3A, 102-103: „Contra autem Dominus perfectum et consummatum docet fieri qui omnibus suis venditis atque in usum pauperum distributis thesaurum sibi condat in caelo. Eum dicit posse se sequi et gloriam dominicae passionis imitari qui expeditus et succinctus nullis laqueis rei familiaris involvitur, sed solutus ac liber facultates suas ad Dominum ante praemissas ipse quoque comitatur", POK 19, 239-240; por. tamże 19; De habitu virginum 7.

${ }^{57}$ Por. De lapsis 12.

${ }^{58}$ Por. Epistula $1,1$.

${ }^{59}$ Por. De habitu virginum 7.

${ }^{60}$ De bono patientiae 3, CCL 3A, 119: „Est enim nobis cum Deo virtus ista communis”.

${ }^{61}$ Por. De catholicae Ecclesiae unitate 15.

${ }^{62}$ De mortalitate 9, CCL 3A, 21: ,[...] magis sit cum diaboli inpugnatione luctandum”.

${ }^{63}$ De catholicae Ecclesiae unitate 1, CCL 3, 249: ,[...] cumque esse nos iubeat ad innocentiam simplices et tamen cum simplicitate prudentes, quid aliud, [...], quam providere nos convenit et sollicito corde vigilantes subdoli hostis insidias intelligere pariter et cavere”, POK 19, 171.

${ }^{64}$ De oratione Dominica 35, CCL 3A, 112-113: ,[...] nulla hora excipitur christianis quominus frequenter ac semper Deus debeat adorari, ut qui in Christo, hoc est in sole et in die vero, sumus 
$\mathrm{Z}$ modlitwą nierozłącznie związane są pokuta oraz nieustanne nawracanie się, którymi winien charakteryzować się prawdziwy chrześcijanin ${ }^{65}$. Powinien on również być „wesołym zawsze i wdzięcznym”66.

3. „Owoc stokrotny" doskonałości - męczennicy. Jak wynika z powyższych rozważań, biskup Cyprian przedstawiał chrześcijanom konkretny wzorzec doskonałości. Co więcej, w oparciu o ten wzorzec, stwierdzał, że chrześcijanie są najdoskonalszymi z ludzi ${ }^{67}$. Wskazując zaś na doskonałych chrześcijan, również w ich gronie wskazywał na tych, którzy mają być szczególnymi wzorami do naśladowania i którzy są - rzec by można - modelowymi chrześcijanami. Ukazywał $\mathrm{w}$ ten sposób model doskonałego chrześcijanina adekwatny do czasów, w których przyszło im żyć.

Jak stwierdzono wcześniej, Cyprian z Kartaginy żył i działał w szczególnym okresie dziejów Kościoła. Srożące się prześladowania wpływały bezsprzecznie na postawy i poglądy chrześcijan tego czasu ${ }^{68}$. Z pewnością dlatego w dziele De habitu virginum, omawiając eschatologiczną nagrodę przynależną wiernym, wskazywał przede wszystkim na dwie grupy, które otrzymają największą nagrodę - dziewice i męczenników. Pisał bowiem:

„Ciasna i wąska jest droga, która wiedzie do żywota, twarda i stroma ścieżka, prowadząca do chwały. Tą ścieżką życia zdążają męczennicy, idą dziewice, kroczą wszelacy sprawiedliwi. Szerokich i przestronnych dróg unikajcie: zabójcze są tam ponęty i śmiertelne rozkosze: tam schlebia diabeł, by oszukiwać, uśmiecha się, by szkodzić, zachęca, by zabijać. Pierwszy owoc setny jest męczenników, drugi sześćdziesiąty wasz jest [dziewic-M.W.]. Jak u męczenników nie ma myśli o ciele i świecie, ani małego, lekkiego i przeczulonego obcowania, tak i u was, których drugą jest nagroda łaski, niech będzie i męstwo gotowe do cierpienia" ${ }^{96}$.

insistamus per totum diem precibus et oremus: et quando mundi lege decurrens vicibus alternis nox revoluta succedit, nullum de nocturnis tenebris esse orantibus damnum potest, quia filiis lucis et in noctibus dies est”, POK 19, 250-251; por. De zelo et livore 16; De oratione Dominica 4; 36.

${ }^{65}$ Por. Epistula 26; De lapsis 29; 35.

${ }^{66}$ Ad Demetrianum 26, CCL 3A, 51: „Neque enim poterit nisi laetus esse semper et gratus qui cum morti fuisset obnoxius, factus est immortalitate securus”; por. tamże 20.

${ }^{67}$ Por. tamże 25; Ad Quirinium I, II.

${ }^{68}$ Por. M. Wysocki, Eschatologia okresu prześladowań na podstawie pism Tertuliana i Cypriana, Lublin 2010, 183-228.

${ }^{69}$ De habitu virginum 21, PL 4, 460-461: „Arcta et angusta est via quae ducit ad vitam durus et arduus est limes qui tendit ad gloriam. Per hunc viae limitem martyres pergunt, eunt virgines, iusti quique gradiuntur. Lata et spatiosa itinera vitate. Lethales illic illecebrae et mortiferae voluptates. Illic diabolus blanditur ut fallat, arridet ut noceat, illicit ut occidat. Primus cum centeno martyrum fructus est, secundus sexagenarius vester est. Ut apud martyres non est carnis et saeculi cogitatio, nec parva et levis, et delicata congressio, sic et in vobis, quarum ad gratiam merces secunda est, sit 
Podobne poglądy zawarł Cyprian w liście 76, będącym zachętą do wytrwania w nowym prześladowaniu w 257 roku. Wspominał w nim, że w ogromnej liczbie wiernych doznających prześladowań w kopalniach i więzieniach, były także dziewice, którym dzięki poniesionemu męczeństwu „,do sześćdziesiątego owocu setny przybył i podwójna chwała do niebieskiej korony je wyniosła" "70. Wskazywał zatem Cyprian na szczególną nagrodę eschatologiczną, którą otrzymać mają dziewice i męczennicy. Nagrodę, która będzie wynagrodzeniem za czyny dokonane w życiu tu na ziemi. Nagroda ta jest wyznacznikiem znaczenia obydwu grup w życiu Kościoła. Pierwsza nagroda przyznawana męczennikom i druga dziewicom wskazuje na ich szczególne miejsce w życiu wspólnoty chrześcijańskiej III wieku, a w sposób szczególny w przedstawianiu obrazu doskonałego chrześcijanina ${ }^{71}$.

Wyjątkowe miejsce męczenników w myśli św. Cypriana przejawia się nie tylko w sferze teologicznej, ale widoczne jest również w sferze leksykalnej, w sposobie pisania o męczennikach i zwracania się do nich. Odnosi się on do nich ze szczególną atencją. Jak do żadnej innej grupy zwraca się do nich ze wyjątkowym szacunkiem. Określa ich jako „najszczęśliwszych i najukochańszych braci” (beatissimi ac dilectissimi fratres) ${ }^{72}$, „najdzielniejszych i najszczęśliwszych braci” (fortissimi ac beatissimi fratres) ${ }^{73}$, "braci najdroższych i najdzielniejszych" (fratres carissimi ac fortissimi) ${ }^{74}$, ,braci najdroższych i najszczęśliwszych" (fratres carissimi ac beatissimi) ${ }^{75}$, „, najdzielniejszych i najwierniejszych żołnierzy Chrystusa" (fortissimi ac fidelissimi milites Christi $)^{76}$. Żadna inna grupa nie jest obdarzona tak licznymi przymiotnikami w stopniu najwyższym. Obdarzał ich ponadto tytułem ,prawdziwych świadków Ewangelii i prawdziwych męczenników Chrystusa (vere evangelii testes et vere martyres Christi) ${ }^{77}$. Pisał też o szczególnej łasce Pana, która w nich

et virtus ad tolerantiam proxima", POK 19, 152-153; por. A. Quacquarelli, Il triplice frutto della vita cristiana: 100, 60 e 30 (Matteo 13, 8 nelle diverse interpretazioni), Roma 1953.

${ }^{70}$ Epistula 76, 6, CCL 3C, 614: ,[...] quibus ad sexagenarium fructum centenus accessit quasque ad caelestem coronam gloria gemina provexit".

${ }^{71}$ Męczeństwo, śmierć za ideę lub bóstwo, znane i cenione były już w świecie pogańskim, a osoby oddające w ten sposób życie były szanowane w społeczeństwie i wskazywane jako wzór do naśladowania. Jednak to chrześcijaństwo nadało szczególny i wyjątkowy rys oddaniu życia za wiarę, por. J.W. Van Henten - F. Avemarie, Martyrdom and Noble Death, London - New York 2002, 1-8; A. Kubiś, Zarys chrześcijańskiej koncepcji męczeństwa, „Communio” 41 (1987) 78-81; tenże, La téologie du martyre au vingtième siècle, Roma 1968; T. Baumeister, Die Anfänge der Theologie des Martyriums, Münster 1980; S. Longosz, Niektóre aspekty teologii męczeństwa w literaturze wczesnochrześcijańskiej, TST 7 (1979) 49-73.

${ }_{72}^{72}$ Por. Epistulae 76, 1 i 7; 28, 1, CCL 3C, 603 i 617; 3B, 133.

${ }^{73}$ Por. Epistulae 76, 1; 28, 1 i 10, 1, CCL 3C, 607, 3B, 133 i 3B, 46.

${ }^{74}$ Por. Epistula 13, 1, CCL 3B, 71.

${ }^{75}$ Por. Epistula 6, 4, CCL 3B, 37.

${ }^{76}$ Por. Epistula 76, 6, CCL 3C, 614.

${ }^{77}$ Por. Epistula 37, 4; CCL 3B, 181. 
działała $^{78}$. Stwierdzał, że Kościót, „matka nasza, chlubi się tym, że niedawno za wyznanie dotknęła was kara, że jako wyznawcy Chrystusa staliście się wygnańcami"79. W jednym z listów tak oto sławił męczenników:

„Dawno już, najdrożsi i tak odważni bracia, przesłałem wam list, w którym radosnymi słowami złożyłem uznanie dla waszej wiary i odwagi. A i teraz głos nasz nie czyni nic innego, jak w pierwszym rzędzie radosnym sercem często, owszem zawsze, głosi chwałę waszego imienia"s0.

Ten głos biskupa Kartaginy wielokrotnie sławił we wspaniały i retoryczny sposób przebieg męczeństwa uczniów Chrystusa ${ }^{81}$, a tym samym ukazywał wyjątkową pozycję męczenników i zachęcał innych wiernych do ich naśladowania.

Dla Cypriana przede wszystkim więc męczennicy - z racji wspomnianych okoliczności - byli wzorami doskonałości ${ }^{82}$. W listach skierowanych do nich wielokrotnie wskazywał na dawany przez nich przykład pozostałym chrześcijanom:

„Staliście się przecież przykładem dla innych braci. Na was powinny wzorować się obyczaje, życie i czyny wszystkich"83.

Gdzie indziej stwierdzał, że wyznawcy „powinni być dla innych wzorem dobrych obyczajów" "84. To właśnie męczennicy opromieniają chwałą trzodę Chrystusa $^{85}$. Oni są jaśniejącym oddziałem żołnierzy Chrystusa, którzy są przykładem dla idących za nimi braci ${ }^{86}$. Ów wzór męczennika dostępny jest dla wszystkich chrześcijan, bez względu na płeć i wiek, na co wskazywał Cyprian

${ }^{78}$ Por. Epistula 28, 1.

${ }^{79}$ Epistula 10, 1, CCL 3C, 46: „Exulto laetus et gratulor, fortissimi ac beatissimi fratres, cognita fide ac virtute vestra, in quibus mater Ecclesia gloriatur, gloriata et nuper quidem cum confessione perstanti suscepta poena est quae confessores Christi fecit extorres", PSP 1, 46.

${ }^{80}$ Epistula 13, 1, CCL 3B, 71: „Et iampridem vobis, fratres carissimi ac fortissimi, litteras miseram quibus fidei et virtuti vestrae verbis exultantibus gratularer, et nunc non aliud in primis vox nostra conplectitur quam ut laeto animo frequenter ac semper gloriam vestri nominis praedicemus", PSP 1, 57.

${ }^{81}$ Por. Epistula 10, 2.

${ }^{82} \mathrm{Na}$ temat rozumienia męczeństwa/wyznania u św. Cypriana por. doskonałą pracę E.L. Hummel, The concept of martyrdom according to St. Cyprian of Carthage, Catholic University of America Studies in Christian Antiquity IX, Washington 1946; zob. też V. Saxer, Morts, martyrs, reliques en Afrique chrétienne aux premiers siècles: les témoignages de Tertullien, Cyprien et Augustin à la lumière de l'archéologie africaine, ThH 55, Paris 1980.

${ }^{83}$ Epistula 13, 3, CCL 3B, 73: „[...] exemplum facti estis ceteris fratribus, ad quorum mores omnium vita et actus debeat provocari”, PSP 1, 58.

${ }^{84}$ Epistula 11, 1, CCL 3B, 57: „[...] confessores, qui exemplo ceteris ad bonos mores esse debuerant".

${ }^{85}$ Por. Epistula 13, 1.

${ }^{86}$ Por. De lapsis 2. 
pisząc o kobietach, które cierpiały dla Chrystusa, stając się tym samym wzorem dla innych niewiast:

„Szczęśliwe są również niewiasty, które razem z wami podzielają chwałę wyznania. Wierząc w Pana, silniejsze od swej płci. I nie tylko bliskie są otrzymania korony, lecz również przez swą stałość, stały się wzorem dla innych niewiast"77.

W wielu swoich pismach biskup Cyprian przywoływał postaci dawnych i współczesnych męczenników, wskazując na konieczność ich naśladowania, na wzór jak pozostawili. W liście 58 wzywał, aby naśladować „sprawiedliwego Abla, [...] Abrahama, przyjaciela Boga, [...] trzech młodzieńców: Ananiasza, Azariasza, Miszaela"88. W innym liście stawiał za wzór i wzywał do naśladowania apostoła Pawła, podkreślając rys martyrologiczny jego życia $^{89}$. Ze współczesnych zaś sobie męczenników przywoływał Cyprian starca Rogacjana ${ }^{90}$ oraz Mappalika ${ }^{91}$; stawiając ich wszystkich za wzór do naśladowania Cyprian wskazywał jednocześnie na motywy tych zachęt - jak można bowiem wnioskować z przytoczonego powyżej fragmentu listu 13 - męczennicy zachowali doskonałość w codziennym życiu ucznia Chrystusa, czyli model doskonałości, który powinien obowiązywać każdego chrześcijanina i dlatego powinni być naśladowani. W tymże liście wyraźnie pisał:

„Musimy wytrwać na trudnej i wąskiej drodze chwały i sławy. Chociaż pokój, pokora i dobre obyczaje są wskazane dla wszystkich chrześcijan, bo według słów Boga patrzy on tylko na karnego i drżącego na jego mowę, to jednak wyznawcy powinni tego tym bardziej przestrzegać i to wypełniać"92.

W innym zaś liście Cyprian przypominał, że męczennicy „powinni być pokorni, skromni i spokojni, strzec chwały swego imienia" ${ }^{93}$. Męczennik zatem, zanim ostatecznie potwierdzi swoją doskonałą przynależność do Chrystusa poprzez cierpienia lub śmierć dla Niego, w codziennym życiu powinien zachowywać wzór doskonałego chrześcijanina, który obowiązuje wszystkich

${ }^{87}$ Epistula 6, 3, CCL 3B, 34: „Beatas etiam feminas quae vobiscum sunt in eadem confessionis gloria constitutae, quae dominicam fidem tenentes et sexu suo fortiores non solum ipsae ad coronam proximae sunt, sed et ceteris quoque feminis exemplum de sua constantia praebuerunt", PSP 1, 41.

${ }^{88}$ Epistula 58, 5, CCL 3C, 325: „Imitemur, fratres dilectissimi, Abel iustum qui initiavit martyria dum propter justitiam primus occiditur. Imitemur Abraham Dei amicum qui non est cunctatus ut filium victimam suis manibus offerret, dum Deo fide devotionis obsequitur. Imitemur tres pueros, Ananiam, Azariam, Misael [...]", PSP 1, 170.

${ }^{89}$ Por. Epistula 14, 2.

${ }^{90}$ Por. Epistula 6, 4.

${ }^{91}$ Por. Epistula 10, 4.

${ }^{92}$ Epistula 13, 3, CCL 3B, 73: „Perseverandum nobis est in arto et in angusto itinere laudis et gloriae, et cum quies et humilitas et bonorum morum tranquillitas Christianis omnibus congruat secundum Dei vocem qui neminem alium respicit nisi humilem et quietum et trementem sermones suos, tunc magis hoc observare et implere confessores oportet", PSP 1, 58.

${ }^{93}$ Epistula 14, 2, CCL 3B, 81: ,[...] humiles et modestos et quietos esse debere”. 
wierzących. Męczennicy bowiem ,przez swe cnoty” stają się wodzami, obecna jest w nich doskonała wiara i pobożność, które winny cechować każdego chrześcijanina ${ }^{94}$. Męczennika nie tworzy zatem tylko sam fakt męczeństwa, ale także fakt przestrzegania i zachowywania wzorca doskonałego chrześcijanina, który został ukazany wcześniej. Codzienne życie chrześcijańskie jest można powiedzieć doskonalone przez męczeństwo. Przez nie, ale i przez spełnianie obowiązków ucznia Chrystusa, męczennik staje się dla innych wzorem - modelem doskonałego chrześcijanina, który o wszystko może prosić Boga i który staje się prawdziwym świadkiem Chrystusa i Jego Ewangelii:

„O co więc prosicie łaskawość Pana, a czego otrzymać nie jesteście godni? Czego nie bylibyście godni wy, którzy tak zachowywaliście przykazania Pana, którzy trzymaliście się ewangelicznej karności i to całą mocą wiary, którzy z niewzruszoną odwagą występowaliście dzielnie w obronie nauki Pana i jego apostołów, i prawdą waszego męczeństwa wzmocniliście chwiejącą się wiarę wielu? Prawdziwi świadkowie Ewangelii i prawdziwi Męczennicy Chrystusa! Na jego korzeniach oparci, na mocnej skale ugruntowani, łączyliście karność z odwagą, pobudzaliście innych do bojaźni Boga, przez swe męczeństwo staliście się wzorem"

Doskonały chrześcijanin - męczennik - według biskupa Kartaginy - winien zatem odznaczać się, podobnie jak każdy chrześcijanin, zachowywaniem przykazań Boga i karnością ${ }^{96}$. W podobny sposób wypowiadał się Cyprian w późniejszym liście z roku 257, kiedy szalały już prześladowania:

„Nie dziwię się, najdzielniejsi i najszczęśliwsi bracia, że Pan za waszą pobożność i wiarę tak was wyniósł na wzniosły szczyt swego chwalebnego uwielbienia, zawsze bowiem, w Jego Kościele odznaczaliście się zachowaniem wiary, przestrzegaliście wytrwale przykazań Pana: w prostocie niewinność, w miłości zgodę, w pokorze skromność, w rządach pilność, we wspieraniu cierpiących czujność, we wspieraniu ubogich miłosierdzie, w obronie prawdy stałość, w zachowywaniu nakazów karność" 97 .

${ }^{94}$ Por. Epistula 76, 1; 28, 1.

${ }^{95}$ Epistula 37, 4, CCL 3B, 181-182: „Quid enim petitis de indulgentia Domini quod non inpetrare mereamini? Qui sic Domini mandata servastis, qui evangelicam disciplinam sincero fidei vigore tenuistis, qui incorrupto honore virtutis cum praeceptis domini et cum apostolis eius fortiter stantes nutantem multorum fidem martyrii vestri veritate solidastis. Vere evangelii testes et vere martyres Christi radicibus eius innixi, super petram robusta mole fundati, disciplinam cum virtute iunxistis, ad timorem dei ceteros provocastis, martyria vestra exempla fecistis", PSP 1, 111.

${ }^{96}$ Por. Epistula 11,$1 ; 13,1 ; 28,1$;

${ }^{97}$ Epistula 76, 1, CCL 3C, 606-607: „Quae quidem vobis, fortissimi ac beatissimi fratres, pro merito religionis ac fidei vestrae accidisse non miror, ut vos sic Dominus ad gloriarum sublime fastigium clarificationis suae honore provexerit, qui semper in Ecclesia eius custoditae fidei tenore viguistis, conservantes firmiter dominica mandata, in simplicitate innocentiam, in caritate concordiam, modestiam in humilitate, diligentiam in administratione, vigilantiam in adiuvandis laborantibus, 
Wymieniwszy zaś wszystkie cechy doskonałego chrześcijanina, które możemy odnaleźć w przedstawionym powyżej opisie modelu doskonałego chrześcijanina, dostępnego dla każdego wiernego, biskup Kartaginy wskazywał na wypełnienie chrześcijańskiej doskonałości, jaką jest męczeństwo:

„Aby zaś do przykładu dobrych czynów niczego nie brakło, zapalacie teraz przez wyznanie (imienia Chrystusa) i cierpienia ciała umysły swych braci do poniesienia boskiego męczeństwa i przez swe cnoty stajecie się wodzami, aby trzoda, idąc za swym pasterzem i czyniąc to, co widzi u swoich zwierzchników, za takież zasługi w ofiarowaniu siebie, przez Pana została ukoronowana"98.

Męczeństwo było więc dopełnieniem chrześcijańskiego życia, pełnym i najdoskonalszym oddaniem się Chrystusowi, naśladowaniem Go, pełnym posłuszeństwem wobec Jego przykazań, całkowitym poświęceniem się, a zatem doskonałym wypełnieniem chrześcijańskiego wzorca, jaki proponował Cyprian.

W samym zaś akcie męczeństwa i cierpienia za Chrystusa męczennik powinien również zachowywać to wszystko, co niesie ze sobą obraz doskonałego chrześcijanina. Mają więc w momencie próby męczennicy naśladować Pana i słuchać wiernie Jego poleceń, mają być pokorni i łagodni, cierpliwi i mężnie znoszący cierpienia, mają gardzić doczesnościąa ${ }^{99}$ Dlatego też Cyprian zachęcał wyznawców:

„Niech [wyznawca - M.W] będzie pokorny i ułożony, niech będzie skromny w swym stosunku do karności, aby tak zwany wyznawca Chrystusa naśladował Chrystusa, którego wyznaje"100.

W innym zaś liście, skierowanym do papieża Korneliusza w obliczu prześladowań, przypominał:

„Zachęcamy was jak możemy, najdroższy bracie, kierując się wzajemną miłością, która nas łączy, ze względu na to, że opatrzność upominającego Pana poucza nas, a miłosierdzie Boże zbawiennie ostrzega, że już blisko jest dzień naszego boju i walki, dlatego zachęcamy, abyśmy nie przestawali z całym ludem usilnie oddawać się postom, czuwaniom, modlitwom. Jest to bowiem nasza niebieska broń, dzięki której dzielnie stoimy i trwamy. To szańce du-

misericordiam in fovendis pauperibus, in defendenda veritate constantiam, in disciplinae severitate censuram", PSP 1, 298.

${ }^{98}$ Epistula 76, 1, CCL 3C, 607-608: „Ac, ne aliquid ad exemplum bonorum factorum deesset in vobis, etiam in confessione nunc vocis et passione corporis fratrum mentes ad divina martyria provocatis duces vos exhibendo virtutibus, ut dum grex pastores suos sequitur et quod fieri a praepositis cernit imitatur, paribus obsequiorum meritis a domino coronetur", PSP 1, 298.

${ }^{99}$ Por. Epistulae 6, 4; 10, 4; 13, 4; 14, 2; 58, 5. 9; 59, 1; De bono patientiae 10, 12, 13, 20; De opere et eleemosynis 24; De mortalitate 11.

${ }^{100}$ De catholicae Ecclesiae unitate 21, CCL 3, 264: „Sit humilis et quietus, sit in actu suo cum disciplina modestus ut, qui Christi confessor dicitur, Christum quem confitetur imitetur". 
chowe i pociski boże, które chronią. Pamiętajmy wzajemnie o sobie, bądźmy zgodni i jednomyślni, nawzajem módlmy się za siebie, cierpienia i uciski wspólną miłością czyńmy lżejszymi i jeśli który z nas za łaską Bożą szybciej uprzedzi drugiego, niechaj i u Pana nasza miłość dalej trwa"101.

Według Cypriana męczennicy chrześcijańscy - podobnie jak i wszyscy doskonali chrześcijanie - ,zawsze radują się w Panu, cieszą się i weselą w Bogu swoim, a zło i przeciwności świata mężnie znoszą w oczekiwaniu dóbr przyszłych i pomyślności"102.

Wielokrotnie podkreślaną przez biskupa Kartaginy cechą doskonałego chrześcijanina-męczennika była jedność z Kościołem, która w sposób szczególny leżała Cyprianowi na sercu. Twierdził on, że męczennicy przede wszystkim trwają w Kościele:

„Nie może być męczennikiem, kto nie jest w Kościele. Nie może dojść do królestwa, kto opuszcza tego, który ma królować (tj. Kościół). Chrystus dał nam pokój, kazał żyć w zgodzie i jedności, przykazał związki przywiązania i miłości nietknięte i nienaruszone zachowywać. Nie może uważać się za męczennika, kto nie dochował braterskiej miłości" ${ }^{103}$.

Męczennik, który wyznał Chrystusa, zachowuje pokój i jedność, „nie złorzeczy, nie czyni zamieszania, nie wywołuje kłótni i sporów, [...] po słowach pochwały nie wyrzuca przeciw braciom i kapłanom Boga wężowej trucizny"104. O takich doskonałych chrześcijanach-męczennikach mógł powiedzieć Cyprian:

„Obecnie zajęliście należyte waszej wierze stanowisko. Zachowaliście prawo Pana o nierozerwalnej miłości i zgody, daliście innym przykład miłości

${ }^{101}$ Epistula 60, 5, CCL 3C, 379: „Hortamur plane quantum possumus, frater carissime, pro caritate mutua qua nobis invicem cohaeremus ut, quoniam providentia Domini monentis instruimur et divinae misericordiae consiliis salubribus admonemur adpropinquare iam certaminis et agonis nostri diem, ieiuniis, vigiliis, orationibus insistere cum omni plebe non desinamus. Incumbamus gemitibus adsiduis et deprecationibus crebris. Haec sunt enim nobis arma caelestia quae stare et perseverare fortiter faciunt. Haec sunt munimenta spiritalia et tela divina quae protegunt. Memores nostri invicem simus, concordes atque unanimes, utrobique pro nobis semper oremus, pressuras et angustias mutua caritate relevemus, et si quis istinc nostrum prior divinae dignationis celeritate praecesserit", PSP 1, 196-197.

${ }^{102}$ Ad Demetrianum 20, CCL 3A, 47: „Exultant semper in Domino et laetantur et gaudent in Deo suo et mala adque adversa mundi fortiter tolerant, dum bona et prospera futura prospectant", POK 19, 318.

${ }^{103}$ De catholicae Ecclesiae unitate 14, CCL 3, 259: „Esse martyr non potest qui in Ecclesia non est; ad regnum pervenire non poterit qui eam quae regnatura est derelinquit. Pacem nobis Christus dedit, concordes atque unianimes esse praecepit, dilectionis et caritatis foedera incorrupta atque inviolata mandavit. Exhibere se non potest martyrem qui fraternam non tenuit caritatem", POK 19, 183.

${ }^{104}$ De catholicae Ecclesiae unitate 21, CCL 3, 265: ,[...] non sit maledica, non turbulenta, non conviciis et litibus perstrepens audiatur, non contra fratres et Dei sacerdotes, post verba laudis, serpentis venena iaculetur", POK 19, 190. 
i pokoju. Prawdziwość Kościoła, jedność ewangelii i nauki, jakich się trzymamy, przez wasze przyłączenie się zyskała mocny węzeł, który je jednoczy; wyznawcy zaś Chrystusa, którzy okazali się chwalebnymi przewodnikami odwagi i chwały, nie stali się uwodzicielami do błędu"105.

Doskonałość, jaka objawiała się w męczennikach i wyznawcach, predystynowała ich do bycia wzorem pośród chrześcijan i to bycia wzorem szczególnym - bycia pasterzami pośród trzody Chrystusa i dlatego Cyprian pisał w jednym z listów:

„Musimy uznać i przyjąć, najukochańsi bracia, dobrodziejstwa Boże, jakimi Pan zechciał łaskawie uświetnić i uczcić swój Kościół w naszych czasach. Dając wolność swym dzielnym wyznawcom i męczennikom chwalebnym, chciał, aby ci, wzniośle wyznawszy Chrystusa, ozdobili potem kler Chrystusowy, sprawując kościelne urzędy"106.

Biskup Cyprian, który - jak stwierdziliśmy wcześniej - rządził Kościołem afrykańskim w okresie szczególnie obfitującym w okazje do oddania życia za wiarę, przyznawał męczennikom szczególną cześć i pozycję, nawiązując do istniejących wzorców ${ }^{107}$. Wspomnianego już męczennika Mappalika stawiał za wzór do naśladowania dla innych męczenników i wyznawców, zachęcając:

„abyście naśladowali tego najszczęśliwszego obecnie męczennika, a także innych uczestników i towarzyszy tej walki, stałych w wierze, w bólu cierpliwych, a w walce zwycięskich" ${ }^{\prime 108}$.

To właśnie męczennicy, z racji niezachwianej wiary i swej wyjątkowej pozycji, byli wyznaczani do szczególnych zadań w Kościele. Wyjątkowość tych wyborów polegała na wynoszeniu do kościelnych godności bez przewidzianych procedur, jako że o nowych męczennikach-kapłanach biskup jedynie powiadamiał bez zasięgania opinii wiernych ${ }^{109}$. W liście 38 Cyprian informo-

${ }^{105}$ Epistula 54, 1, CCL 3B, 252: „Nunc vero et vos congruentem fidei vestrae tenorem atque individuae caritatis et concordiae legem dominica pace tenuistis et exemplum ceteris dilectionis et pacis vestro itinere fecistis, ut ecclesiae veritas et evangelii ac sacramenti unitas quae a nobis tenebatur vestro etiam consensu ac vinculo necteretur nec confessores Christi erroris duces fierent qui virtutis et honoris auctores laudabiles extitissent", PSP 1, 141.

${ }^{106}$ Epistula 39, 1, CCL 3B, 186: „Agnoscenda et amplectenda sunt, fratres dilectissimi, beneficia divina quibus ecclesiam suam Dominus inlustrare temporibus nostris et honestare dignatus est, commeatum dando bonis confessoribus suis et martyribus gloriosis, ut qui sublimiter Christum confessi essent clerum postmodum Christi ministeriis ecclesiasticis adornarent”, PSP 1, 113.

${ }^{107}$ Por. M. Sieniatycki, Św. Cyprian o męczennikach i wyznawcach, AK 17 (1926) 154-165; A. Brent, Cyprian's reconstruction of the Martyr tradition, JEH 53 (2002) 241-268.

${ }^{108}$ Epistula 10, 4, CCL 3B, 53: „Istum nunc beatissimum martyrem et alios participes eiusdem congressionis et comites in fide stabiles, in dolore patientes, in quaestione victores ut ceteri quoque sectemini", PSP 1, 49.

${ }^{109}$ Por. Epistula 38, 1; zob. A. Brent, Cyprian and the question of Ordinatio per Confessionem, StPatr 36 (2001) 323-337. 
wał o wyborze na stanowisko lektora dzielnego młodzieńca Aureliusza, który był „młody co do wieku, ale dojrzały co do czci. Stoczył bowiem podwójną walkę. [...] Skoro pokonał urzędników i prokonsula, na wygnaniu zwyciężył zadawane mu katusze"110. Wobec licznych cierpien i kar, których doświadczył Aureliusz oraz licznych cnót, którymi się odznaczał, Cyprian postanowił wynieść go do godności lektora, ponieważ „Bóg go zachował, aby stał się dla innych przykładem co do karności kościelnej” i zachwalał również, że nie wie, co ma bardziej w nim sławić „,czy chwałę ran, czy czystość obyczajów, czy też jego niezmierną odwagę, czy też godną podziwu jego skromność"111. Jednak, co należy podkreślić, $\mathrm{z}$ racji swego trwania przy wierze $\mathrm{w}$ czasie prześladowań, Aureliusz według Cypriana:

„zasłużył na wyższe stopnie święceń, na większą godność nie ze względu na jego lata, lecz na zasługi. Uznaliśmy jednak, aby rozpoczynał od obowiązku lektora. Nic bowiem nie przystoi bardziej głosowi, który wyznał chwalebnie Boga, jak rozbrzmiewać przy uroczystym odczytywaniu słów bożych, jak po wzniosłych słowach, które głosiły mękę Chrystusa, czytać ewangelię, która jest źródłem męczenników. Nic bardziej nie przystoi jemu, jak z narzędzia tortur wstąpić na mównicę"112.

Męczeństwo było więc bezpośrednim powodem wyniesienia Aureliusza, poza przyjętymi procedurami, na stanowisko lektora i jego szczególnej pozycji we wspólnocie kartagińskiej. Podobna sytuacja zachodziła w przypadku Celeryna, który został lektorem z powodu licznych cierpień doznanych podczas prześladowań w roku 250. Stwierdził bowiem Cyprian:

„nie jest słuszne i nie przystoi, aby ten, kogo Pan tak uczcił godnością niebieskiej chwały, nie piastował urzędu zaszczytnego w Kościele" ${ }^{113}$.

Obaj męczennicy wyniesieni zostali do godności lektora, ponieważ „wyznawca jednak najbardziej może się przysłużyć braciom czytaniem ewangelii, po-

${ }^{110}$ Epistula 38, 1, CCL 3B, 183-184:, ,[... [ minor in aetatis suae indole, sed maior in honore: gemino hic agone certavit, [...] ut post magistratus et proconsulem vinceret, post exilium tormenta superaret", PSP 1, 112.

${ }^{111}$ Epistula 38, 1, CCL 3B, 184: ,[...] illum divinitus reservatum qui ad ecclesiasticam disciplinam ceteris esset exemplo [...]. Nec invenio quid in eo praedicare plus debeam, gloriam vulnerum an verecundiam morum, quod honore virtutis insignis est an quod pudoris admiratione laudabilis", PSP $1,112$.

${ }^{112}$ Epistula 38, 2, CCL 3B, 184: „Merebatur talis clericae ordinationis ulteriores gradus et incrementa maiora, non de annis suis sed de meritis aestimandus. Sed interim placuit ut ab officio lectionis incipiat, quia et nihil magis congruit voci quae Deum gloriosa praedicatione confessa est quam celebrandis divinis lectionibus personare, post verba sublimia quae Christi martyrium prolocuta sunt evangelium Christi legere unde martyres fiunt, ad pulpitum post catastam venire [...]", PSP 1, 112-113.

${ }^{113}$ Epistula 39, 1, CCL 3B, 187: ,[...] nec fas fuerat nec decebat sine honore ecclesiastico esse quem sic Dominus honoravit caelestis gloriae dignitate", PSP 1, 114. 
nieważ każdy, kto słucha $\mathrm{z}$ jego ust ewangelię, zachęca się do naśladowania wiary lektora" ${ }^{114}$. Celem takiego wyniesienia męczenników było - jak zauważał biskup - ,aby wierni ich naśladowali, widząc w nich najwyższy stopień chwały, a największy, co do pokory"115. Mieli być oni zatem wzorem doskonałości dla wiernych, którym będą służyć i przewodzić. Podkreślał bowiem Cyprian, że posługa lektora nie jest końcem ich posługi w Kościele kartagińskim. Pisał do swych wiernych:

„Wiedzcie jednak, że tymczasowo ustanowiliśmy ich lektorami [...]. Wiedzcie, że już postanowiliśmy wynieść ich do godności prezbiteratu" $" 16$.

Godność męczeństwa była jednak tak znaczna, że Cyprian nakreślił przed wspólnotą przyszłe plany dotyczące obu męczenników „w swych późniejszych i starszych latach powinni z nami zasiadać", co wskazuje na godność biskupią, którą powinni posiąśćc ${ }^{117}$. Podobnie postąpił Cyprian z Numidykiem, którego zaliczył do grona kleru kartagińskiego, planując wynieść go do godności biskupiej po swoim powrocie z miejsca schronienia ${ }^{118}$. Widzimy więc wyraźnie, że męczeństwo w sposób szczególny predestynowało do pełnienia posług w Kościele kartagińskim i było znakiem szczególnego wybrania przez Boga do otrzymania święceń. Trudno przyznać, żeby Cyprian uznawał tortury i męczeństwo jako zastępujące święcenia. Stwierdzał bowiem wyraźnie, że on i będący z nim jego towarzysze udzielili święceń Aureliuszowi ${ }^{119}$. Męczeństwo potwierdzało więc tylko szczególny wybór i rolę, którą ma pełnić dany człowiek we wspólnocie Kościoła - ma przede wszystkim świadczyć o chrześcijańskiej doskonałości i być jej wzorem.

Jak zauważyliśmy wcześniej, męczennicy rekrutowali się z różnych grup. Tak jak doskonałość chrześcijańska jest dostępna każdemu, tak i męczeństwo - jej najdoskonalsze zwieńczenie - może ukoronować życie każdego wiernego. W Kościele jednak wskazywał na dwie grupy, którym męczeństwo powinno być jakby najbliższe: dziewice i kapłanów. I dlatego zachęcał w sposób szczególny te dwie grupy do osiągnięcia doskonałości w męczeństwie. Do dziewic kierował zatem następującą zachętę:

„Żadnemu chrześcijaninowi nie przystoi, a najmniej dziewicy, uważać na jakąkolwiek chwałę, czy honory ciała, lecz jedynie szukać słowa bożego, starać

${ }^{114}$ Epistula 39, 4, CCL 3B, 190: „Nihil est in quo magis confessor fratribus prosit quam ut, dum evangelica lectio de ore eius auditur, lectoris fidem quisque audierit imitetur", PSP 1, 115.

${ }^{115}$ Epistula 39, 5, CCL 3B, 191: ,[...] ut dum nihil in honore sublimius, nihil in humilitate summissius a fratribus cernitur, hos eosdem fraternitatis sectata comitetur", PSP 1, 115-116.

${ }^{116}$ Epistula 39, 5, CCL 3B, 191-192: „Hos tamen lectores interim constitutos sciatis [...]. Ceterum presbyterii honorem designasse nos illis iam sciatis”, PSP 1, 116.

${ }^{117}$ Epistula 39, 5, CCL 3B, 192: „[...] sessuri nobiscum provectis et corroboratis annis suis”, PSP $1,116$.

${ }^{118}$ Por. Epistula 45.

${ }^{119}$ Por. Epistula 38, 2. 
się o dobra, na wieki trwające. Jeżeliby zaś przyszło z ciała szukać chwały, to chyba wtedy, gdy za wyznanie imienia chrześcijańskiego idzie na tortury, gdy niewiasta okazuje się silniejszą od męczących ją mężczyzn, gdy znosi ogień, krzyż, miecz, albo dzikie zwierzęta, by otrzymać koronę. To są drogie naszyjniki, to są piękniejsze ozdoby ciała"120.

Najpełniejszą więc chwałę może osiągnąć dziewica przez męczeństwo, dodając, jak zauważono to wcześniej, do swego owocu ów owoc strokrotny. Podobnie kapłani i biskupi, którzy z racji swej funkcji kapłańskiej mają być wzorami dla wierzących i praktykującymi wzór doskonałości ucznia Chrystusa:

„Jeśli zaś wszyscy, bez wyjątku mają się trzymać w karności, to tym bardziej zwierzchnicy i diakoni. Mają się starać o to, aby swym życiem i obyczajami dawać innym przykład i wzór"121.

Jednak to cierpienia za Chrystusa, gotowość na męczeństwo i jego doświadczenie stawiają biskupów i kapłanów na szczególnym miejscu. Czynią ich jeszcze doskonalszymi wzorami dla wiernych. Tak oto pisał Cyprian w jednym ze swych listów:

„Chociaż byliście gotowi i mieliście wolę poddać się każdym katuszom, jednakże Pan od nich was uchronił i zachował Kościołowi. Przez wasz powrót, godność, jaką biskup pozyskał dzięki swemu wyznaniu, nie została umniejszona, lecz owszem jego powaga biskupia jeszcze wzrosła. Stoi bowiem przy ołtarzu Boga biskup, który zachęca lud nie słowami, lecz czynami, aby się uzbroił do wyznania i do poniesienia męczeństwa, i wobec zbliżania się Antychrysta przygotowuje żołnierzy do walki nie tylko mowami i zachętą swego głosu, lecz przykładem wiary i odwagi""122.

Męczeństwo było więc szczególnym przykładem i jakby ukoronowaniem życia ludzi, którzy przede wszystkim mieli trwać na drodze doskonałości chrze-

${ }^{120}$ De habitu virginum 6, PL 4, 446: „Neminem christianum decet, et maxime virginem non decet, claritatem ullam computare carnis et honorem, sed solum appetere sermonem Dei, bona in aeternum mansura complecti. Aut si in carne sit gloriandum, tunc plane quando in nominis confessione cruciatur, quando fortior femina viris torquentibus invenitur, quando ignes aut cruces aut ferrum aut bestias patitur ut coronetur. Illa sunt carnis pretiosa monilia, illa corporis ornamenta meliora", POK $19,142$.

${ }^{121}$ Epistula 4, 3, CCL 3B, 21-22: „Et cum omnes omnino disciplinam tenere oporteat, multo magis praepositos et diaconos curare hoc fas est, qui exemplum et documentum ceteris de conversatione et moribus suis praebeant", PSP 1, 35; por. De lapsis 6; De catholicae Ecclesiae unitate 5.

${ }^{122}$ Epistula 61, 2, CCL 3C, 381-382: ,[...] ut cum vos parati fueritis et prompti omne subire supplicium, Dominus tamen vos poenae subtraheret et Ecclesiae reservaret. Regredientibus vobis breviata non est in episcopo confessionis suae dignitas, sed magis crevit sacerdotalis auctoritas, ut altari Dei assistat antistes qui ad confessionis arma sumenda et facienda martyria non verbis plebem sed factis cohortetur et imminente antichristo paret ad proelium milites non solo sermonis et vocis incitamento sed fidei et virtutis exemplo", PSP 1, 198; por. Epistulae 9, 1; 60, 1. 
ścijańskiej. Przez nie stawali się doskonałym wzorem dla współwyznawców i realizowali model doskonałego chrześcijanina, który sami ukazywali w swym nauczaniu.

\section{$* * *$}

Model doskonałego chrześcijanina, choć niezmienny w swych fundamentalnych założeniach, odzwierciedla zawsze prądy i wydarzenia epoki, w której jest propagowany. Na wzór doskonałego chrześcijanina, który przedstawiał św. Cyprian, biskup Kartaginy, miały bezsprzecznie wpływ prześladowania, które dotknęły Afrykę prokonsularną w III wieku i które wielu chrześcijan uczyniły wyznawcami i męczennikami. Dlatego też modelem doskonałego chrześcijanina dla biskupa Cypriana był chrześcijanin-męczennik, który doskonale wypełniał w życiu codziennym Boże nakazy i w sposób najdoskonalszy zjednoczył się z Chrystusem w cierpieniach i śmierci. Ów wzór doskonałego chrześcijanina-męczennika jeszcze przez kilkadziesiąt lat po Cyprianie - do panowania cesarza Konstantyna Wielkiego - był głównym modelem doskonałego chrześcijanina. Ukazywany przez wielu Ojców Kościoła, w najwyraźniejszy sposób przedstawiany był w tzw. zachętach do męczeństwa, które powstawały w III wieku. Pomimo ustania prześladowań w 313 roku i przeniesienia akcentu doskonałości chrześcijańskiej na życie ascetyczne, wzór chrześcijanina-męczennika, w którego stworzeniu ważną rolę odegrał biskup Kartaginy Cyprian, pozostał wzorcem do naśladowania po dziś dzień.

\section{THE MODEL OF THE PERFECT CHRISTIAN IN ST. CYPRIAN'S WRITINGS}

\section{(Summary)}

The article shows the model of the perfect Christian depicted by the Bishop of Carthage, St. Cyprian. This model is particularly interesting since it was formed during the persecution, which had a major impact on shaping the image of the perfect Christian. This paper consists of three main parts: the first - St. bishop Cyprian of Carthage and his time - in which the circumstances of his pastoral work and his works are given, the other - Perfection for all - shows a model of perfection that St. Cyprian proposed to all believers, and in the third part, the martyrs - ,a fruit a hundredfold" of perfection - are portrayed. To them Cyprian admitted the highest degree of Christian perfection. For bishop Cyprian the Christian-martyrs, who perfectly fulfilled God's commandments in everyday life and in the most perfect way they united themself with Christ in the suffering and in the death, were primarily a perfect model of the Christians. And this model of perfect Christianmartyr for decades after Cyprian - till the reign of Emperor Constantine the Great - was the main model of a perfect Christian. 